\title{
The start of it all? Heritage, labour and the environment in regional Queensland
}

\author{
Robert Mason and Rebecca Damjanovic \\ r.mason@griffith.edu.au, rebecca.damjanovic@griffithuni.edu.au
}

\begin{abstract}
The Great Shearers' Strike of 1891 transformed Australian politics and created the context for the election of the first 'labourist' government in the world. This nationally significant history is reflected in Barcaldine's central heritage precinct, with a large monument to the Tree of Knowledge and spacious Australian Workers Heritage Centre. The Centre was established as the 'National Monument' to working men and women when it was opened by Prime Minister Bob Hawke in 1991. The Centre is one of a number of industrial museums in the Central West, and exists alongside the Stockman's Hall of Fame in nearby Longreach. The recent increase in tourism by Grey Nomads has resulted in a more concerted effort to formulate a clear heritage discourse in Barcaldine, one that draws on the town's labour heritage. This increased emphasis on the heritage of the Great Shearers' Strike has further politicised an already fraught heritage, and distanced the community from its local heritage spaces and stories. This article reflects on long-standing narratives relating to the local environment as a means to articulate contested heritage discourses, situate the significant labour history and reinforce the local community's engagement in its heritage.
\end{abstract}

\section{Introduction}

The town of Barcaldine was at the centre of Australian political debate in 1891, as fears of civil war captivated the colonies. The town, more than 500 kilometres inland from the coastal port of Rockhampton, was the site of the largest shearers' camp in the colony of Queensland. More than 1000 men, women and children flew the Eureka Flag over the camp, determined to improve their working conditions in the face of firm opposition from local pastoralists. In response, the government in Brisbane deployed the army, police and auxiliaries to the district, attempting to bolster the pastoralists' position and weaken the strikers' capacity to resist. The government's strategy was successful. The strike for better conditions failed, and its leaders were condemned to hard labour on Saint Helena Island. The defeat at 
Barcaldine, and other defeats that followed soon afterwards, convinced the workers' leaders that the surest pathway for change was through the ballot box. As a result, the Labor Party was formed. ${ }^{1}$ Soon after this, in December 1899 , that party was elected to be the first 'labourist' government in the world, and would (briefly) govern the colony of Queensland.

Barcaldine is now firmly entrenched in the mythology of the labour movement and that of the Australian Labor Party (ALP). Multiple prime ministers, premiers and union leaders have paid homage at the Tree of Knowledge, under which the strike leaders met and the Labor Party was formed. Yet much else has changed in the town. The wool industry collapsed from the 1980s, with the number of sheep, pastoralists and shearers plummeting. Those graziers who remain on the land are now contending with severe drought. Many former shearers now live in the town, where they are increasingly elderly and isolated. The town's economy has diversified to include government and private enterprise, many of which focus on attracting tourism from the tens of thousands of 'Grey Nomads' who pass through the town each year. Many of these travellers stop to look at the redeveloped heritage precinct at the Tree of Knowledge, and some stay longer to visit the nearby Australian Workers Heritage Centre.

This article explores how rural communities draw on contested heritage in times of economic and environmental stress. This is especially pertinent in a town such as Barcaldine, given its rich history and national significance. Yet intensified use of the Great Shearers' Strike as a central narrative with which to attract tourists has exacerbated long-standing community tensions. Through interviews with a range of community members, as well as observation and analysis of local ephemera, this article argues that the labour heritage remains a key narrative of community identity; however, in the process of forming touristic heritage, labour history has come to exclude other long-standing and fractured narratives of local identity. Without diminishing the town's role as the symbolic birthplace of the labour movement, the article suggests that a recognition of the entanglement of multiple narratives in an environmental landscape offers a means for touristic heritage to connect people, land and industry in a more inclusive manner.

\section{Political history, industrial heritage}

The Great Shearers' Strike of 1891 has become central to the history of the Australian labour movement. In the midst of economic depression in 1890, Barcaldine became home to one of the most famous and symbolically important labour protests in Australia's history. Pastoralists in Western Queensland had long been desperate to depress wages to remain profitable, and shearers' earnings were consequently among the lowest in the English-speaking world. ${ }^{2}$ These shearers had limited options to improve their conditions, other than protests or attempted negotiations through the nascent unions. The shearers' formation of unions prompted the pastoralists to act likewise, as the divisions between the two sides hardened. Confident in their support from the government, the pastoralists goaded the shearers to strike in 1891. Amid sensationalist reporting, the colonial government in Brisbane permitted the formation of armed civilian groups to assist pastoralists and prevent what was portrayed as the strikers' attempt at violent revolution. ${ }^{3}$ Strike camps spread throughout the west, and their leaders met at 
Barcaldine to plan a response. It was in Barcaldine that one of the largest camps was formed, and more than 1,000 shearers and their families established a camp under the Eureka Flag. Faced with the police, army and pastoralists (and damaged by unfavourable weather conditions), the strike collapsed after several months. Its leaders were arrested and sentenced to hard labour.

The formation of the Labor Party drew on a succession of disastrous losses by the workers' movement, and various unions met at Barcaldine in 1892 from where they issued the first 'Manifesto of the Queensland Labor Party to the People of Queensland', consolidating their reputation as 'a party of reformers opposed to the powerful privileged groups of Queensland society'. ${ }^{4}$ This sense of connectivity between strikers' commitment to social and economic justice, the history of the people of Queensland and the local community remains central to the heritage of Barcaldine more than 125 years later.

Sheila Watson explains that museums might be more effective at articulating community identities if they focused on the 'historiographic needs and historical perception of audiences', rather than drawing on academic narratives with little regard to the way history is used by the local community. ${ }^{5}$ During her research in a working-class town in England, Watson identified that a 'historical narrative had emerged from a consensual view of [the] past' that drew on the diverse experiences associated with the town's fishing industry. ${ }^{6}$ The local museum had created a sense of community that transcended socio-economic divisions within the locality. Laurajane Smith and Gary Campbell explain that the role of industrial heritage as a meeting place for a community is complex and predominantly emotional. ${ }^{7}$ It involves not just remembering the past, but also providing a means for selfrecognition in the present and into the future. It is from that recognition that established community values and narratives are strengthened and adapted.

Many historic sites have the capacity to evoke particular connections to the past, and the process of heritage interpretation is never static. Instead, it is an ongoing process during which understanding is 'contested, worked and re-worked by people according to particular individual, social and political circumstances'. ${ }^{8}$ Leidulf Mydland and Wera Grahn highlight that stakeholders (local, institutional and political) will have differing goals in advocating for the preservation of heritage sites, and that the sites can become a form of contact zone, where different meanings of community, assumptions and aspirations are expressed. ${ }^{9}$

There is a persistent tradition in outback Australian communities of the so-called 'timeline approach to history', in which an 'imagined linearity of colonial history ... is evoked by the themes of "discovery", of "firsts", and of the "pioneers". ${ }^{10}$ In this context, 'the pioneer' has been presented as an individual, an agent of history, a symbol of nationalism and the Australian character. ${ }^{11}$ The sequencing of a narrative theme of firsts and pioneers is a means to organise history into a linear pattern of development and progress as the European imprint on the landscape was consolidated. The effect is to institutionalise the privileging of certain voices and perspectives over others, and order an otherwise unruly and harsh landscape. The development of a timeline approach is similarly not static, as linear history is retold through memorials, books and celebrations, 'continually adding on to this timeline by metaphorically extending narratives ... to new circumstances'. ${ }^{12}$

Smith explains that the use of foundational narratives is central to the authorised heritage discourse in large parts of regional Australia, establishing the white 'settler' 
at the centre of the landscape's significance. As community stakeholders seek to affirm the value of particular sites through 'heritage making'; they must 'negotiate and legitimise particular narratives, and the cultural values that underpin them', often silencing alternative histories in the process. ${ }^{13}$ As Crooke notes, the formulation of a community's narration of itself through heritage affirms positions of political and social authority that can challenge some members' sense of inclusion in their local heritage. ${ }^{14}$ As Smith suggests with regards to the Stockman's Hall of Fame in regional Queensland, the result can be to embed exclusionary narratives of white male heroes in rural spaces. ${ }^{15}$

\section{'I had it on my wall - "nothing's too good for the worker"'}

Caravans and campervans line the grass verges of Barcaldine's main street in early mornings, as Grey Nomads prepare to leave the town for the drive out to Longreach and Winton or head south as the extreme heat of summer approaches. Many such tourists remain for several months in winter, enjoying the town's relaxed atmosphere, well-tended gardens and central location. Motels and caravan parks dot the entry into the town, and are frequently close to capacity with both tourists and government workers. Many Grey Nomads prefer to stay out of town at the weir, where the local council has proved basic services to encourage the travellers to stay and spend their money in local businesses. The town's main street runs parallel to the railway line that was once at the heart of Barcaldine's economy. The railway is now much diminished in the life of the district, with most haulage taken by road rather than rail. Five pubs face the train station, sitting 'like companion pieces to Barcaldine's working history'. ${ }^{16}$ In front of the train station, and dominating the town's skyline, is the redeveloped precinct around the Tree of Knowledge.

The original Tree of Knowledge was a large, 200-year-old ghost gum, under which the leaders of the Great Shearers' Strike had met and where the first Labor Party Manifesto had been issued. It had been a site for visitors to stop and take a photograph at the iconic location for many decades. The tree had been marked with a plaque, but there had been few other attempts to signal its significance for tourists. This changed when the tree was poisoned in 2006. Despite attempts to save it by the local community, the original Tree of Knowledge died soon after. There was no firm consensus in the community about how to respond to the loss. Some locals wanted a small monument, while others hoped for a larger interpretive centre. Under leadership from the newly formed regional council, and partly funded by a Q150 grant, a significant redevelopment of the site was undertaken. The result was a controversial realigning of the main road, which has inconvenienced and irritated a number of local businesses, and the installation of a major piece of public art that commemorates the tree.

The original tree's trunk and root system were partially preserved by experts in Brisbane before being returned to Barcaldine. The preserved remains were positioned in the tree's former location, and placed under a glass floor that allows visitors to see the roots below the ground. A large dark wooden structure has now been suspended around the trunk and remaining branches. Known variously by locals as 'the box' or 'the tank stand' (the exterior appears to support the town's water tank when viewed from a distance), 3600 pieces of recycled wood hang from the structure's roof. These pieces of wood frame what would had been the 
(a)

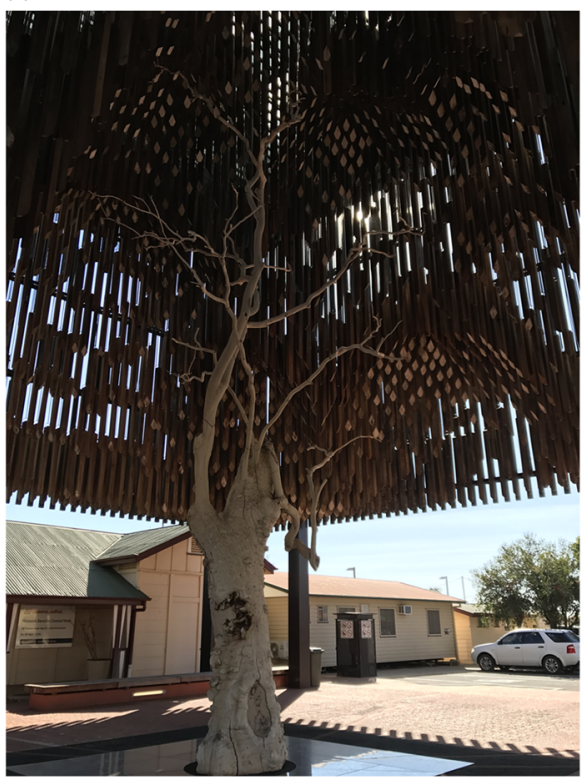

(b)

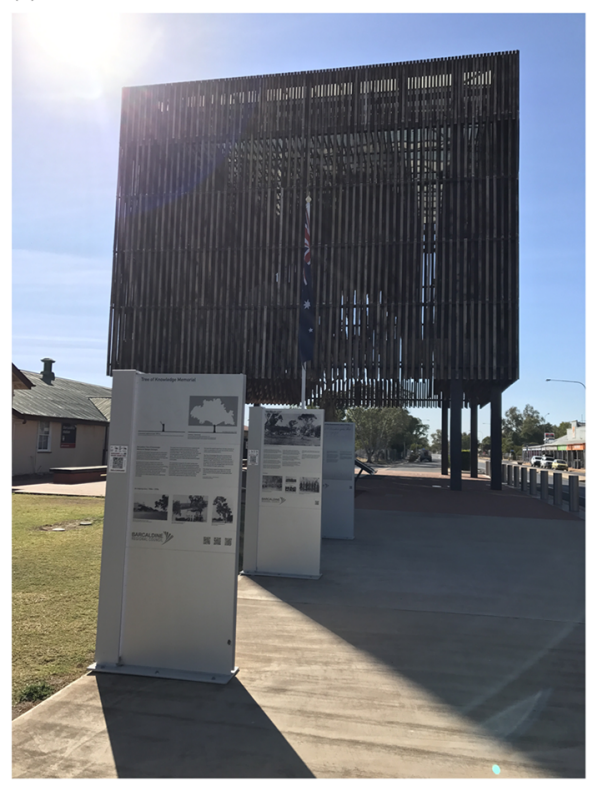

Figure 1

Tree of Knowledge precinct, Barcaldine (Images: Authors).

maximum extension of the tree's canopy in the 1890s. At night, dramatic green floodlighting further simulates the tree's presence through the illusion of leaves shining through the exterior structure. In developing the project, architects had sought to create a more 'interactive place' in which visitors would be called on to remember and recreate the events of 1891.

A series of interpretative panels line the pavement on the approach to the redeveloped Tree of Knowledge. Tourists, eager to pause and stretch their legs, generally spend a considerable period of time reading the panels. The text begins with an affirmation of the events' evocation of Australia's national identity, stating optimistically that 'there existed among them a caring, a desire to help each other, that became the famed "mateship" of Australian legend' ${ }^{17}$ The panels proceed to narrate the events at Barcaldine chronologically, establishing an equivalence with the Eureka Stockade as 'one of only two armed insurrections between white settlers and government-backed forces' in Australian history. ${ }^{18}$ Of legendary significance to Labor Party supporters, the tree's significance for others is less clear. In an attempt to situate and explain the site's significance to all Australians, tourists are invited to visit the nearby Australian Workers Heritage Centre (AWHC) - 'unequivocally, the National Monument to our working men and women' and where visitors 'are confronted by reminders of how our pioneers struggled to shape the quality of life and freedom that we all enjoy today'. ${ }^{19}$

The AWHC was founded in 1991, when it was opened by then Prime Minister Bob Hawke on the 100-year anniversary of the Great Shearers' Strike. 'The nation's only dedicated and ongoing tribute to the rich history, heritage and traditions of all working Australians' is located a short distance from the Tree of Knowledge 
precinct, set back from the main road. ${ }^{20}$ At the height of the tourist season, up to fifty tourists visit each day, although this can drop down to fewer than five in the hot summer months. Visitor numbers to the Centre have declined since the redevelopment of the Tree of Knowledge. Staff at the AWHC feel that the additional spectacle at the Tree of Knowledge precinct has caused people to feel that they have already had the touristic experience and connection with history, without the need for additional time in the AWHC.

The AWHC goes to considerable lengths to entice visitors through its doors, its employees chatting reassuringly with potential entrants about how the Centre tells a story of 'the labour movement and of all workers, rather than only the unions or Labor Party'. ${ }^{21}$ In the words of one staff member to an unsure would-be visitor, the Centre communicates 'Australia's story of the worker'. The entry area contains an audio-visual display that partially reinforces this message, narrated by the founder and CEO Bob Gleeson. This film affirms that there is 'a social contract between our generation and all Australians alive today, and those who went before us, and those who are not yet born. It is a matter of [asking] "What serves the people?"' The moral exhortation for visitors to continue the location's radical tradition is clear. Gleeson continues, 'What I'd say, if I was one of them [the strikers] sitting here today talking to you, what I'd say is, "Stop being complacent, start empowering yourself, and understand that this is your country, because at the end of the day, you will be responsible for it". ${ }^{22}$ While this message encourages many tourists to enter, other visitors politely distance themselves with words such as, 'I've never been a Labor voter' or (to the bemusement of staff in the centre) 'It all looks a bit too serious for me'. Those people who are happy to proceed pass through the entrance into a verdant billabong around which various buildings are arranged.

Visitors move through the site on a predetermined route between separated historical buildings. The precinct is large, occupying both sides of a former public road that has since been enclosed, as well as adjoining blocks of land. Each building in the AWHC is broadly associated with the labour history of Queensland, and has been purchased and relocated to the site for the purpose of housing an exhibition related to the building's previous use. Thus visitors begin their tour in the former railway station building from Kunwarara, complete with a period steam locomotive, to learn about the lives and struggles of railway workers. They pass through a sequence of historical buildings, ranging from a police lock-up and one-teacher school to a former emergency services station and post office. Each building contains didactic panels and objects associated with its former use. The aesthetic effect is to mimic a living village museum.

The AWHC is not a folk museum, but rather is an attempt to convince visitors of the need for a renewed Australian compact to advance social and economic justice based on the legacy of the Great Shearers' Strike. Rather than a heroic historical timeline of the workers' struggles against oppressive employers and the state, each building in the Centre provides discrete narratives of industry-specific attempts to improve workers' conditions. Each building recommences the workers' story in the late colonial era before tracing events to the contemporary moment. At times, these industrial and social narratives overlap (such as the implicit intersections between the police display and shearers' exhibition, which both touch on the groups' respective roles in the iconic 1891 strike). At other times, displays appear 


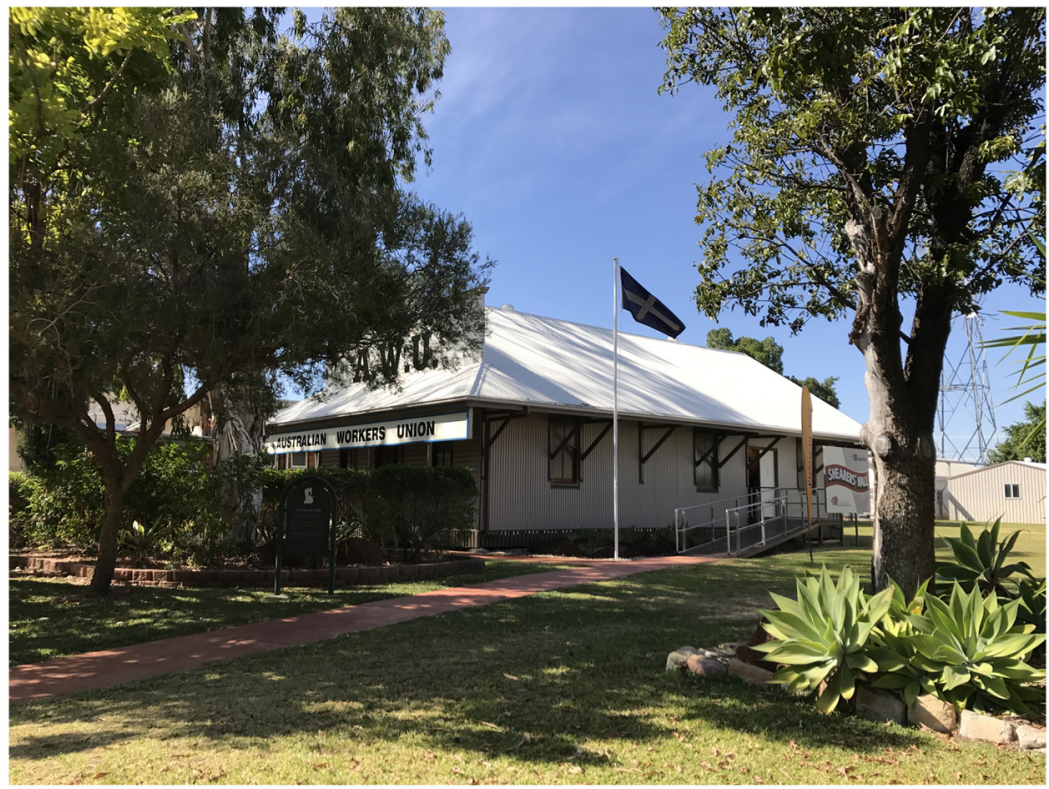

Figure 2

The Shearers' Hall, Australian Workers Heritage Centre (Image: Authors).

unconnected to a broader history (such as the Main Roads exhibit that focuses on the evolution of the roles of those workers who survey and build infrastructure in the face of harsh environmental conditions). Unfunded by government, the AWHC was nonetheless founded with the support of the (then Labor) Queensland Government, whose government departments assisted in the establishment of the various displays. This is not immediately clear to the visitor, however, although the support of various trade unions in rooms associated with their industry is obvious. The result is to provide a syndicalist history of workers' rights in Queensland and Australia, at times connecting across industries and at times unique to that sector of employment.

Recognition of the location of the AWHC in Barcaldine is uneven throughout the precinct, given the Centre's development and alignment with unions and government departments. The first time the iconic strike is introduced is within the 25 metre-high Bicentennial Tent. The tent physically dominates the site, but is now somewhat in need of repair and is at risk of being impacted by wind and rain during storms. At the centre of the tent is a recreation of the cells in Saint Helena Island, where the strike leaders were incarcerated. At the mercy of the elements, the multimedia aspects of the display no longer function. The overall effect is to emphasise the sacrifices made by the strikers' leadership, although the rhetorical question posed by the display - 'a union's battle for better working conditions or a conspiracy to overthrow the establishment?' - is left unresolved.

Exiting the tent, visitors enter the exhibition called the Shearers' Hall (opened in 2013 with support from the Australian government and the Australian Workers' Union). The displays in the building provide a more successful example of an attempt to tell the history of the events of 1891 that connect building, location and 
significance through a syndicalist framework. The exhibition is housed in the former Queensland Shearers' Union hall from nearby Blackall, and recognises the central role played by that union (an antecedent of the Australian Workers' Union) in the original strike, for which Barcaldine is famous. In the words of the exhibition's introduction:

This is an exhibition about the birth of the Australian labour movement. It shows how the Great Shearers' Strike of 1891 led, not to the civil war that was feared, but to the rise of the Australian Workers Union, the Australian Labor Party, our modern system of party politics, and Australia's unique form of industrial arbitration. It also shows how the building you are standing in was part of that story.

Subsequent panels trace the biographies of union and strike leaders who would later enter politics as elected officials, including Anderson Dawson, 'the first head of a parliamentary socialist government anywhere in the world'. The exhibition recognises that the party's first manifesto was proclaimed under the nearby Tree of Knowledge, but that this was only the first step in a series of ongoing struggles for workers' conditions. While the focus is on the shearing industry, the displays make clear that the workers' demands, including free education for all and public ownership of railways, was a struggle on behalf of all Australians.

Despite repeated iterations that the AWHC is a living monument to all workers, the local community remains at a distance from the Centre. There is a strong local consensus that the town's labour history is a resource via which Barcaldine can attract tourists and persuade them to stop on the way to Longreach. With the council-led Tree of Knowledge redevelopment, the labour history 'brings a bit of limelight to the town' that should not be forgotten. ${ }^{23}$ There is hope among locals that the time tourists spend in Barcaldine will teach them about life in the local community. There is far less consensus that the AWHC contributes to that story of life in the town and district. Many locals who are not active in the labour movement feel the Centre is overtly political in its aspirations, and that this focus should be reduced if it is to broaden its appeal. Many non-activists associate key heritage sites in the town with divisive politics or with particular stakeholders in the community. While they recognise the value of the AWHC for attracting outsiders, they worry that it is not representative of the local community in which it is located. In the words of one local professional, 'What of the stories of women, of Aboriginal locals, of graziers? Where are they? ${ }^{24}$ That all of these histories are indeed present in the AWHC displays does not mitigate the lack of local engagement with the site.

Part of this hesitancy is an ambivalence about the significance of the Great Shearers' Strike to contemporary Barcaldine. Of a dozen people interviewed in depth, only three felt that the strike was the most important thing to have happened in the region. For local labour activists, the AWHC is crucial and an affirmation of the town's national significance. In response to a discussion about history's relevance today, one stalwart of the labour movement worried that, 'Young people today aren't interested in politics. The only thing I can keep saying to them is something I had on my wall - "Nothing's Too Good for the Worker". 25 Other residents felt that it was pointless to draw lessons from the Great Shearers' Strike, feeling that 'the world has just passed them by'. ${ }^{26}$ Even former shearers were frequently fatalistic, saying, 'It's all in the past. It sort of divided people. A "between you and us" sort of thing' that would not help the town prepare for the future. ${ }^{27}$ 
Nonetheless, there is local pride in and ownership of the events that happened here. For one woman who had moved to the town two decades earlier:

It doesn't matter whether you are Labor, or conservative, or indifferent. Every single person in Australia has benefited from that history, from that act that went down in history, because it was for better pay and working conditions. So, for all those people who aren't labour - they all enjoy a 38-hour week. They all enjoy workplace health and safety. They all enjoy annual leave. So from a workers' perspective, what they did, how can you not be a part of that ${ }^{28}$

\section{'Without it, there'd be no Barcaldine'}

The history of the Great Shearers' Strike of 1891 transformed Australian politics and society. The use of labour heritage remains divisive, though, and many locals feel that the resolute use of the strike to attract tourists is unrepresentative of the community. Yet there is consensus on the importance of the region's unique heritage for building local resilience. ${ }^{29}$ Tourists are to be welcomed into the town, but only 'so long as people are explaining the right things to them about what's here'. ${ }^{30}$ Whose stories should be told, and by whom, remains disputed by locals. The architectural firm tasked with redeveloping the central heritage precinct acknowledges that the site's 'value came in making the most of [Barcaldine's] existing character and heritage. As a town, as a region, they have their own character and that is the thing that actually keeps people interested. ${ }^{31}$ Yet the increasing emphasis placed on labour heritage as single discourse risks disempowering locals, including those who remain emotionally invested in alternative histories as equally representative of the region.

The Festival of the Tree of Knowledge, held on the Labour Day weekend in May, is the pre-eminent expression of local society, cohesion and community. Commencing with a Rugby League match, it includes markets, drag, horse and goat racing, shearing and, of course, the Labour Day parade and march. Events centre on the Tree of Knowledge precinct and nearby showgrounds, reclaiming the junction of the two central highways for the festivities. The three-day event is an attempt to attract tourists to the town, but is also a celebration of community and heritage. The Labour Day parade is viewed as a local institution, but regularly attracts labour activists from across the country. This creates a tension in the celebrations as being both politically partisan and locally inclusive. As the comments by June Wilkes make clear, a sense of 'cohesiveness of what they're celebrating still hasn't come.'.32 As a result, tensions have grown steadily regarding the use of labour heritage in the town's annual celebration.

This division was clearest in the 2016 celebrations to commemorate 125 years since the iconic strike of 1891 . Thousands marked the occasion, joined by Prime Minister Bob Hawke, Deputy Prime Minister Wayne Swan and Queensland Premier Annastacia Palaszczuk. The added historical significance of the commemoration rendered the event's political connotations particularly overt. Many locals bridled at southern politicians coming to the town to narrate local history and its significance in a manner with which many in the community did not agree. While labour activists celebrated, other locals felt that they had lost a sense of ownership in their heritage. Some refused to attend future celebrations, some alleged financial irregularities on the part of organisers and yet others suggested that they would start 
their own parallel festival for the future. The debate 'tore the community apart' and considerably hampered efforts to unite a community already under stress from a severe drought. ${ }^{33}$

The increasing commodification of tourism and labour heritage as the town's primary tourist attraction, has accentuated existing historical divisions within the town. As locals readily discuss, the town was the birthplace of the United Pastoralists' Association (now known as AgForce), as well as the Labor Party. Graziers have long been suspicious of the potential economic benefit of tourism to the region, and did not engage particularly in its development. ${ }^{34}$ The initial committee tasked with developing the AWHC was careful to include a spectrum of political views though, and the opening ceremony in 1991 involved hundreds of locals eager to join in the spectacle. Yet, criticism soon emerged that 'our tourist attraction was turned into a labour shrine ... Our tourist venture has been filched by a political party, and one that arrogantly thinks it has the monopoly on ideals of freedom and justice. ${ }^{35}$ Others regarded it as 'a cuckoo's egg which required a nest, and the Labor Party stalwarts left in Barcaldine provided it'. ${ }^{36}$ Such views reflected the sharp political divide within the town at a time of recession and restructuring of the wool market.

Attitudes to heritage remain a point of contention within the community. While the Shearers Hall in the AWHC does recognise the graziers' vulnerability to the price of wool during the 1890s, the history of the wool industry is not fully addressed in the region. The nearby woolscour in Blackall is not widely visited by tourists, and there is minimal liaison between local heritage sites to coordinate themes or visitor information. Thus the three working museums of the AWHC, the Woolscour and the Stockman's Hall of Fame tell fragmented stories of otherwise interconnected industries. Renovated pastoralists' properties at nearby Lara, tours of pastoralist stations that are organised by the tourist information centre and the site of the foundation of the Pastoralists' Association at the local Shakespeare Hotel are similarly presented in isolation from the history of the workers and of industrial development in the region.

As the town's labour heritage has become a focus for attracting tourists, alternative heritages have become silenced. A number of these narratives focus on the district's unique environment, and have long-standing traditions that complement the nationally significant labour heritage. The town initiated the Artesian Festival to celebrate ninety years since Barcaldine was founded in 1976. Barcaldine had three artesian wells at the turn of the century, with others in surrounding stations, and could claim the first free-flowing artesian bore in Queensland. The festival was intended to be a biannual celebration in coordination with the neighbouring towns of Blackall, Winton and Longreach. Each town would develop a festival that could attract tourists and locals to celebrate the region's interconnected working heritage. The inaugural Artesian Festival attracted more than 5000 locals to the streets to watch the parade. Displays of sheep shearing were matched with tours of the historical bores and stations. In the words of the Barcaldine and District Historical Museum, opened as planning for the first Artesian Festival was underway, 'Barcaldine can lay claim to one of the most significant historical events ever to happen in Australia, and that is the discovery of the Great Artesian Basin. It was at Back Creek, some thirty-nine kilometres east of the town, on the Capricorn Highway, that the first artesian water was struck on the Great Artesian Basin early in 1886. ${ }^{37}$ 


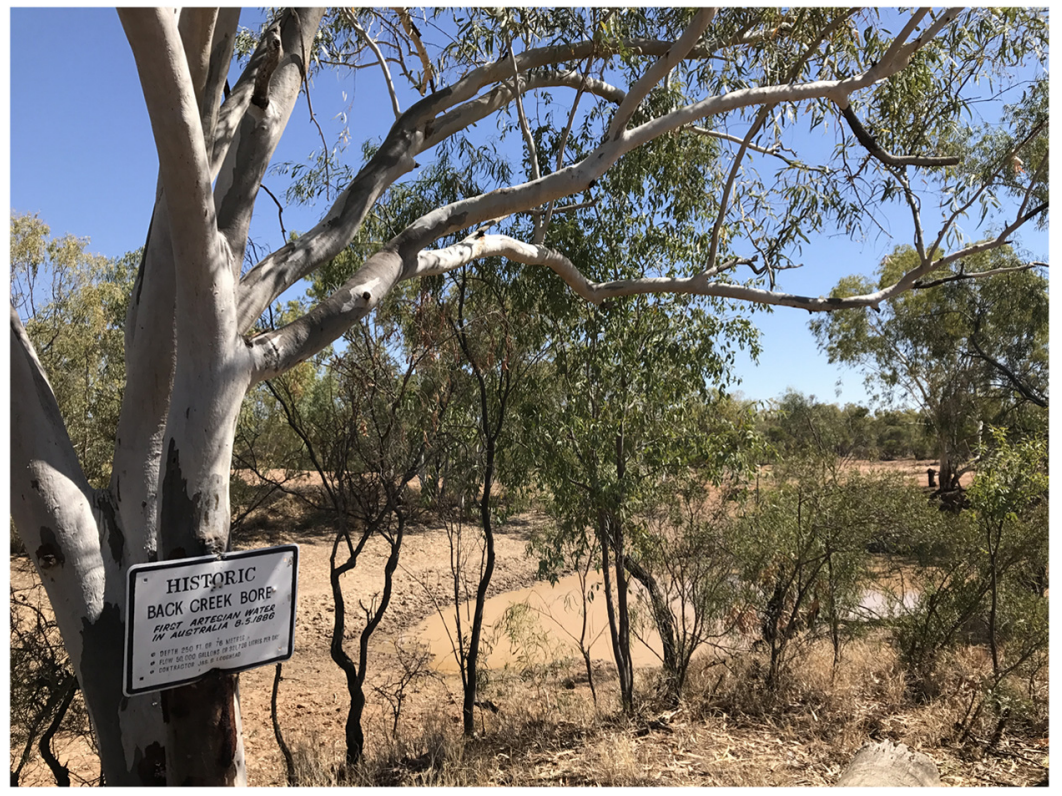

Figure 3

Back Creek Bore (Image: Authors).

Although the festival was only repeated on a handful of occasions, the Great Artesian Basin remains a central component of community memory. Locals repeatedly raise the town's connection with the Great Artesian Basin as 'the most significant thing to have happened in Barcaldine'. In the words of one woman, 'without it, there'd be no Barcaldine'. ${ }^{38}$ The recent development of the Lara Wetlands area to the south of the town, and its enthusiastic support by the community, similarly speak to an awareness of the artesian bores as axiomatic to the town's past and touristic future. In the enthusiastic words of one local tourism operator, 'it's not just what you see, it's what's under the land that makes the area so special: the artesian water, the different soils, the trees, the grasses' ${ }^{39}$

There is the potential for the bores to reinvigorate community engagement with the town's industrial heritage. The Central West's industrial development would not have been possible without the bores that underpinned both Barcaldine district and town, and the history of water in the region is one of hardship and endurance that is at the heart of the outback narrative. Emma Jones' comment that 'no one wants to see a genocide' during drought ${ }^{40}$ speaks to the environmental precarity of tourism in the outback. The presence of water in the Great Artesian Basin and landscape also provides a contextualised history of resilience and nature. It connects tourists and locals, as well as community, with their much-loved locality. As Mayor Bob Chandler asserted, 'Tourism is the future. The drought is hurting everyone. Making visitors welcome is what it's all about. We have to make them feel they are part of the survival of the bush, which they are. ${ }^{41}$

The billabong that is at the Centre of the AHWC is fed directly from one of the town's original bores. Of those interviewed who expressed some reservation at the Centre's perceived political agenda, all expressed happy memories of going to the 
billabong with family members and friends. Most acknowledged that they would engage incidentally with the heritage buildings on site while feeding the ducks, entering a couple of rooms as part of the family ritual. The fact that the AWHC is no longer in a financial position to be fully open to the local community as a shared resource is the cause of some concern among the community, where water is seen as a valued shared asset.

One of the most successful recent events held at the AWHC was a concert to support farmers affected by drought, which coincided with the otherwise divisive 125 anniversary of the strike. A free event, it was supported by thousands of locals who came into the town from stations and surrounding townships to listen to country music artist Graeme Connors around the AHWC billabong. The organising committee was delighted that 'the artist tapped into that. He made it about the struggle and the things that were relevant out here. He resonated with the story of life and trying to make a living out here. He had an affinity with it. ${ }^{42}$ While the associated Tree of Knowledge Festival proved extremely divisive, this event united the community around water and narratives of shared struggle.

\section{Conclusion}

The Great Shearers' Strike of 1891 transformed Australian politics, and created the context for the election of the first 'labourist' government in the world. This nationally significant history is reflected in Barcaldine's central heritage precinct, with a large monument to the Tree of Knowledge and spacious Australian Workers Heritage Centre. Similarly to other centres in the Central West region, the town has long sought to celebrate its identity through festivals and museums. The recent increase in tourists, and tourism's increasing importance to the local economy, have resulted in a more concerted effort to formulate a clear heritage discourse capable of establishing a sense of significance and authenticity. This has paradoxically not strengthened the community's relationship with its labour heritage, but has instead increased the sense of local contestation. While the labour history has long been politicised and contested, it is now perceived to deny alternative heritage discourses and to distance the community from its local heritage.

Attempts by council and the Queensland Government to lead and develop an authorised heritage discourse in Barcaldine have marginalised local stakeholders in the AWHC and elsewhere. They have silenced earlier narratives that foregrounded industrial histories within the environmental context of regional Queensland. The focus on site, rather than local stories and relationships with place, is particularly problematic, with contested histories that focus on conflict and struggle. Framing a sense of place through a fuller recognition of local stories reveals the multiple heritage landscapes in the region, but does so in a way that reveals the sites' relationship with each other and with the contemporary community.

Despite its significance to the town, the Central West and Australia, the site of the first free-flowing Artesian bore remains almost unmarked and largely unknown by tourists; yet it is central to community narratives of identity on all sides of politics. At a time of heightened environmental awareness, the heritage of the Great Artesian Basin connects the Aboriginal and non-Aboriginal residents with an industrial heritage that has transformed the region and nation. The AWHC speaks to a core 
part of Australian history and its political development as a progressive parliamentary democracy. It is one part of a regional labour heritage that is yet to be fully connected with landscape as a resource for communities that remain under considerable economic and environmental pressure.

\section{Acknowledgements}

The authors would like to acknowledge with gratitude the generous help and support provided by Bob Gleeson AM, Chief Executive Officer of the Australian Workers Heritage Centre.

\section{Notes}

1 The party was subsequently renamed the Australian Labor Party in 1912.

2 Stuart Svensen, The shearers' war (Carlisle: Hesperian Press, 2008), 234.

3 Francis Gordon Clarke, The history of Australia (Westport, CT: Greenwood Press, 2002).

4 J.B. Dalton, 'An interpretative survey: The Queensland Labour movement', in D.J. Murphy, R.B. Joyce and Colin A. Hughes (eds), Prelude to power: The rise of the Labor Party in Queensland (Brisbane: Jacaranda, 1970), 9.

5 Sheila Watson, 'History museums, community identities and a sense of place: Rewriting histories', in Simon Knell, Suzanne MacLeod and Sheila Watson (eds), Museum revolutions: How museums change and are changed (New York: Routledge, 2007), 160.

6 Watson, 'History museums', 164.

7 Laurajane Smith and Gary Campbell, “Nostalgia for the future”: Memory, nostalgia and the politics of class', International Journal of Heritage Studies, 23(7) (2017).

8 Christopher Tilley, 'Introduction: Identity, place, landscape and heritage', Journal of Material Culture, 11(1-2) (2006), 7.

9 Leidulf Mydland and Wera Grahn, 'Identifying heritage values in local communities', International Journal of Heritage Studies, 18(6) (2012); Elizabeth Crooke, 'The politics of community heritage: Motivations, authority and control', International Journal of Heritage Studies, 1(1-2) (2010).

10 Elizabeth Furniss, 'Timeline history and the Anzac myth: Settler narratives of local history in a north Australian town', Oceania, 71(4) (2001), 283.

11 Laurajane Smith, 'A pilgrimage of masculinity: The Stockman's Hall of Fame and Outback Heritage Centre', Australian Historical Studies, 43(3) (2012), 474.

12 Furniss, 'Timeline history', 284.

13 Smith, 'A pilgrimage', 474.

14 Crooke, 'The politics'.

15 Smith, 'A pilgrimage'.

16 Andrew Bain, 'Get your kicks on the other Route 66', Sydney Morning Herald, 31 May 2014, http://www.traveller.com.au/queensland-road-trip-get-your-kicks-on-the-other-route-66$393 c c$, accessed 7 October 2017.

17 'The start of the story', Tree of Knowledge Monument, Barcaldine, 2017.

18 ibid.

19 'A Centre for all Australians', Tree of Knowledge Monument, Barcaldine, 2017, 
20 'Visit the Australian Workers Heritage Centre', Australian Workers Heritage Centre, Barcaldine, 2017.

21 Australian Workers Heritage Centre employee, conversation with authors, Barcaldine, 4 September 2017.

22 Australian Workers Heritage Centre, Introduction Video, 2017.

23 Rodger Smith, interview with authors, Barcaldine, 1 September 2017.

24 Emma Jones, interview with authors, Barcaldine, 4 September 2017.

25 Rodger Smith, interview with authors, Barcaldine, 1 September 2017.

26 John Stuart, interview with authors, Barcaldine, 31 August 2017.

27 Ron Wilson, interview with authors, Barcaldine, 3 September 2017.

28 June Wilkes, interview with authors, Barcaldine, 2 September 2017.

29 ibid.

30 John Stuart, interview with authors, Barcaldine, 31 August 2017.

31 Michael Lavery, quoted in Michael Bleby, 'Outback Queensland town puts itself on the map', Financial Review, 5 December 2016, 32.

32 June Wilkes, interview with authors, Barcaldine, 2 September 2017.

33 ibid.

34 'Tourism in Barcaldine', Longreach Leader, 30 June 1989, 2; Rodger Smith, interview with author, Barcaldine, 1 September 2017.

35 'Heritage Centre or ALP shrine?', Longreach Leader, 10 May 1991, 2.

36 'Criticism of Heritage Centre site', Longreach Leader, 28 June 1991, 2.

37 History of Barcaldine and District Didactic Panel 2017, Exhibition Room of Australian Workers Heritage Centre.

38 Emma Jones, interview with authors, Barcaldine, 4 September 2017.

39 Alan Smith, cited in Earl Levey, 'Travel: Learning from Barcaldine's Tree of Knowledge', Sunshine Coast Daily, 4 May 2016, https://www.sunshinecoastdaily.com.au/news/travellearning-from-barcaldines-tree-of-knowledge/3010498, accessed 15 October 2017.

40 Emma Jones, interview with authors, Barcaldine, 4 September 2017.

41 Bob Chandler, cited in Levey, 'Travel'.

42 Pam Davis and June Wilkes, interview with authors, Barcaldine, 1 September 2017. 